\title{
Sandflies (Psychodidae: Phlebotominae) survey in an urban transmission area of visceral leishmaniasis, Northeastern Brazil
}

\author{
Pesquisa de flebotomíneos (Psychodidae: Phlebotominae) em área urbana \\ de transmissão de leishmaniose visceral no Nordeste do Brasil \\ Sthenia Santos Albano Amóra ${ }^{1,2}$; Claudia Maria Leal Bevilaqua ${ }^{1 *}$; Francisco Marlon Carneiro Feijó ${ }^{2}$; \\ Paula Gabriela Melo de Oliveira ${ }^{2}$; Gislayne Christianne Xavier Peixoto ${ }^{2}$; Raimundo Nonato de Sousa ${ }^{3}$; \\ Nilza Dutra Alves² Lorena Mayana Beserra de Oliveira ${ }^{1}$; Iara Térsia Freitas Macedo \\ ${ }^{1}$ Laboratório de Doenças Parasitárias, Universidade Estadual do Ceará - UECE \\ ${ }^{2}$ Laboratório de Microbiologia Veterinária, Universidade Federal Rural do Semi-Árido - UFERSA \\ ${ }^{3}$ Núcleo de Endemias Transmissíveis por Vetores, Secretaria de Saúde Estadual do Ceará
}

Received July 22, 2010

Accepted October 20, 2010

\begin{abstract}
Visceral leishmaniasis (VL) is a major public health challenge in Brazil, especially in states where it is endemic. The aim of this study was to investigate the relationship of sand fly population density with environmental variables (temperature, rainfall and relative humidity) in urban areas of the city of Mossoró, Rio Grande do Norte, Northeastern Brazil. Sand flies were captured with Center Disease Control (CDC) traps installed monthly in the intra and peridomicile of three houses. Data analysis was based on the chi-square test and linear regression. A total of 7,347 sand flies were captured, being 93.85\% Lutzomyia longipalpis and 6.15\% Lutzomyia evandroi. Sand flies were more commonly found in the peridomicile and there was no difference between the number of males and females. The variables rainy season as well as relative humidity and rainfall, alone or together, did not have an effect on sand fly population density. However, high temperatures had a negative effect. The study of the behavior of sand flies in specific units of endemic areas can provide input to public health authorities for planning appropriate VL vector control measures.
\end{abstract}

Keywords: Lutzomyia longipalpis, Lutzomyia evandroi, seasonality, climate, Rio Grande do Norte State.

\section{Resumo}

A leishmaniose visceral (LV) é um grande desafio para a saúde pública no Brasil, particularmente nos estados onde é endêmica. O objetivo deste estudo foi verificar a relação da densidade populacional de flebotomíneos com as variáveis ambientais (temperatura, precipitação de chuva e umidade relativa do ar) em bairros urbanos de Mossoró, Rio Grande do Norte. Os flebotomíneos foram capturados com armadilhas CDC instaladas mensalmente no intra e peridomicílio de três casas. A análise dos dados foi baseada no teste Qui-quadrado e na regressão linear. Foram capturados 7.347 flebotomíneos, sendo 93,85\% Lutzomyia longipalpis e 6,15\% Lutzomyia evandroi. Os flebotomíneos foram encontrados mais comumente no peridomicílio e nenhuma diferença significativa entre o número de machos e fêmeas foi observada. As variáveis estação chuvosa, bem como a umidade relativa e precipitaçáo de chuva, associadas ou isoladas, não influenciou a densidade populacional dos flebotomíneos. No entanto, a alta temperatura afetou essa densidade de forma negativa. Portanto, este estudo específico em áreas endêmicas é importante, porque as agências de Saúde Pública podem usar essas informaçóes para um planejamento adequado das medidas de controle de vetores LV.

Palavras-chave: Lutzomyia longipalpis, Lutzomyia evandroi, sazonalidade, clima, Rio Grande do Norte.

${ }^{*}$ Corresponding author: Claudia Maria Leal Bevilaqua

Laboratório de Doenças Parasitárias, Programa de Pós-graduação em Ciências

Veterinárias, Universidade Estadual do Ceará - UECE, Campus do Itaperi,

Av. Paranjana, 1700, CEP 60740-000, Fortaleza - CE, Brazil;

e-mail: claudiamlb@yahoo.com.br

Financial support: Dr. Bevilaqua is a CNPq researcher. 


\section{Introduction}

In Brazil visceral leishmaniasis (VL) is caused by Leishmania chagasi transmitted to humans mainly through the bite of infected females of Lutzomyia longipalpis sand flies (PINTO et al., 2010). This disease remains a major public health challenge in Brazil, especially in states where it is endemic (PAULA et al., 2009). Studies focused on the vector and environmental conditions are key for assessing the transmission risk of this tropical disease (MICHALSKY et al., 2009) and can provide input that will help to determine the most appropriate methods of vector control (DIAS et al., 2007).

Sand flies are frequently found in natural ecotopes, such as tree trunks, animal shelters, fallen leaves, cracks in rocks and caves (GALATI et al., 2003), as well as in rural and urban environments characterized by domestic animal shelters and human dwellings, demonstrating the adaptation of these insects to anthropic environments (BARATA et al., 2008). L. longipalpis is well adapted to living with humans and domestic animals (REBÊLO, 2001) and can resist adverse conditions and exploit new environments, thereby facilitating VL transmission.

$\mathrm{VL}$ is endemic in the state of Rio Grande do Norte, northeastern Brazil, and in recent years there was an increase of reported cases in many municipalities (CORTEZ et al., 2007, XIMENES et al., 2007). However, data on the presence and distribution of $L$. longipalpis in the city of Mossoró has been generally inadequate to draw an eco-epidemiological profile of VL in this municipality. In addition, high prevalence of VL in dogs in several districts of Mossoró (AMÓRA et al., 2006; MATOS et al., 2006) shows the need to assess the sand fly frequency in domiciliary areas. This study aimed to investigate phebotomine sand flies in areas of intense VL transmission in Mossoró and to describe the relationship between the ecology of sand flies and environmental variables.

\section{Material and Methods}

\section{Study area}

The city of Mossoró is located $285 \mathrm{~km}$ from the state capital Natal ( $37^{\circ} 20^{\prime} 39^{\prime \prime} \mathrm{W}$ and $05^{\circ} 11^{\prime} 15^{\prime \prime} \mathrm{S}$ and $16 \mathrm{~m}$ altitude above see level). It has an area of $2,110,207 \mathrm{~km}^{2} ; 85 \%$ of its population of 234,390 inhabitants live in the urban area (INSTITUTO BRASILEIRO DE GEOGRAFIA E ESTATÍSTICA, 2007). The average annual temperature is around $27.5^{\circ} \mathrm{C}$ with maximum $36{ }^{\circ} \mathrm{C}$ and minimum $21{ }^{\circ} \mathrm{C}$. The average relative humidity is between 59 and $76 \%$. The climate is semi-arid with low rainfall and two well-defined seasons: the rainy season, from January to April and extending as late as June (500 to $700 \mathrm{~mm} /$ year) and drought (INSTITUTO DE DEFESA DO MEIO AMBIENTE, 2002).

The entomological investigation was conducted at Abolição, Aeroporto and Rincão districts of Mossoró, classified as areas of intense VL transmission (MINISTÉRIO DA SAÚDE, 2006).

\section{Capture and identification}

The reasons for choosing domiciliary areas included recent L. longipalpis capture history, presence of abundant vegetation, domestic animals and organic matter accumulation in the peridomicile. Three human dwellings with poor sanitary conditions were selected for the study, one from each district. Sand fly captures using CDC light traps were carried out on a monthly basis during four consecutive nights, from 6:00 p.m. to 6:00 a.m., from January to December 2007. One trap was placed in the peridomicile and a second one inside each dwelling, preferably in animal shelters, as proposed by the Brazilian Ministry of Health (MINISTÉRIO DA SAÚDE, 2006).

The insects captured were identified in the Laboratory of Veterinary Microbiology at the Universidade Federal Rural do Semi-Árido (UFERSA). Female specimens were clarified and dissected on slides and covered with slips for observation under an optical microscope (ARANSAY et al., 2000). Sand fly identification was performed according to GALATI (2003).

\section{Data analysis}

Environmental variables - temperature $\left({ }^{\circ} \mathrm{C}\right)$, relative humidity (\%) and rainfall $(\mathrm{mm})$ - were provided by the UFERSA weather station. The male/female ratio, rainy season influence and capture site (intradomicile or peridomicile) were analyzed by a chi-square $\left(\chi^{2}\right)$ test. The correlation between environmental variables and sand fly population was tested by multiple or single linear regression with Pearson's coefficient using SigmaStat 3.1.

\section{Ethics committee}

The study was approved by the Research Ethics Committee of Universidade Estadual do Ceará as part of a research project entitled "Biological control and entomological surveillance of Lutzomyia longipalpis in the city of Mossoró, Rio Grande do Norte" (protocol nr. 07465297-4).

\section{Results and Discussion}

A total of 7,347 sand flies were captured, $93.85 \%$ of which were L. longipalpis $\left(\chi^{2}=2,825.12, \mathrm{df}=1, \mathrm{p}<0.05\right)$. The remaining sand flies were Lutzomyia evandroi. There was no numeric difference between males and females of L. longipalpis, but more male L. evandroi were caught $\left(\chi^{2}=1.95, \mathrm{df}=1, \mathrm{p}<0.05\right)$. The sand flies were more commonly found in the peridomicile $(70.48 \%)$ in all districts and months $\left(\chi^{2}=616.18, \mathrm{df}=1, \mathrm{p}<0.05\right)$ (Table 1$)$.

The presence of Leishmania vector species explains the active foci of human VL in the area studied, as reported in the municipality of Barreirinhas, Maranhão (REBÊLO et al., 2010). The districts studied are located in the periphery of the city, with abundant vegetation, domestic animals and organic matter, creating favorable conditions for sand fly breeding and population growth, corroborating XIMENES et al. studies (2000). These conditions are known to favor the presence of L. longipalpis (MICHALSKY et al., 2009), the predominant phlebotomine species in the city. Similar results were found in a previous monitoring survey by the same research group (AMÓRA et al., 2010).

Lutzomyia evandroi was found in the same ecotopes of L. longipalpis. The same was seen in 30 other municipalities in the State of Rio Grande do Norte, where L. longipalpis remains 
Table 1. Distribution of Lutzomyia spp. by species, sex and capture site during the phlebotomine sand fly survey study. Mossoró, Rio Grande do Norte State, northeastern Brazil, 2007.

\begin{tabular}{|c|c|c|c|c|c|c|}
\hline \multirow[t]{2}{*}{ Sand fly } & \multicolumn{3}{|c|}{ Sex } & \multicolumn{3}{|c|}{ Capture site } \\
\hline & Female & Male & Total & Intradomicile & Peridomicile & Total \\
\hline L. longipalpis & $3,435 \mathrm{Aa}$ & $3,460 \mathrm{Aa}$ & $6,895 a$ & $2,071 \mathrm{Aa}$ & $4,824 \mathrm{Ba}$ & $6,895 \mathrm{a}$ \\
\hline L. evandroi & $205 \mathrm{Ab}$ & $247 \mathrm{Bb}$ & $452 \mathrm{~b}$ & $98 \mathrm{Ab}$ & $354 \mathrm{Bb}$ & $452 b$ \\
\hline Total & $3,640 \mathrm{~A}$ & $3,707 \mathrm{~A}$ & 7,347 & $2,169 \mathrm{a}$ & $5,178 \mathrm{~B}$ & 7,347 \\
\hline
\end{tabular}

Capital letters compare the columns and lower case letters the lines. Different letters indicate significantly different values by the chi-square test ( $\mathrm{p}<0.05)$.

prevalent (XIMENES et al. 1999, 2000; QUEIROZ et al., 2009; AMÓRA et al., 2010). This finding maybe related to male predominance in $L$. evandroi populations and/or that this species is still in process of adaptation with flies preferably feeding on wild animals (XIMENES et al., 1999; QUEIROZ et al., 2009). However, $L$. evandroi has not so far been implicated as a leishmaniasis vector (LAINSON; RANGEL, 2005).

Female sand flies are the transmitting agents of Leishmania due to their hematophagous feeding habit and they were consistently found throughout the year. Nevertheless, no numeric difference was found between female and male Lu. L. longipalpis, in contrast to previously published studies reporting male predominance (XIMENES et al., 2000; BARATA et al., 2005; MICHALSKY et al., 2009; QUEIROZ et al., 2009). This finding also contrasts with that of a monitoring survey previously performed in Mossoró (AMÓRA et al., 2010) that found a higher number of female flies. It increases the risk of transmission and explains the increase in VL cases in the city.

The significantly higher proportion of sand flies in the peridomicile was also reported in other municipalities in Rio Grande do Norte (XIMENES et al., 2000, 2007), in the city of Mossoró, as mentioned earlier (AMÓRA et al., 2010), and in Montes Claros, state of Minas Gerais, southeastern Brazil, where sand flies were captured near domestic animals (MONTEIRO et al., 2005). These findings can be explained by the devastation of large wild areas for economic exploration, bringing the disease to the periphery of urban centers. Vectors and hosts are forced to migrate to human peridomicile in search of food (BARATA et al., 2005). In this scenario, environment degradation may affect the maintenance of ecological processes and the balance of the enzootic cycle of certain infections, causing a major health public impact, as seen with leishmaniasis in Barreirinhas and the National Park in Maranhão (REBÊLO et al., 2010).

It is also important to note the high number of L. longipalpis captured inside the houses, including many females engorged after a blood meal on humans or animals. These data illustrate the endophilic behavior of the vector and emphasize the possibility of VL transmission in the intradomicile (BARATA et al., 2005; MONTEIRO et al., 2005; MISSAWA; DIAS, 2007; XIMENES et al., 2007; MICHALSKY et al., 2009).

Lutzomyia longipalpis was present every month of the year, with peaks in May and July, and monthly captures were significantly different $(\mathrm{p}<0.05)$ (Table 2). VL vector showed a slight seasonal distribution, tending to increase during rainy periods. The environmental variables studied were statistically different $(p<0.05)$, especially monthly average rainfall and March was the most humid month. During the study it rained $943.2 \mathrm{~mm}$ and the average relative humidity for the rainy period was $74.75 \%\left(\chi^{2}=0.87\right.$, $\mathrm{df}=1, \mathrm{p}>0.05)$. The temperatures remained almost constant and relative humidity varied slightly (Table 2 ). The relative humidity and rainfall, alone or together, did not have an effect on sand fly population density $\left(\mathrm{R} \leq-0.189, \mathrm{r}^{2} \leq 0.036, \mathrm{p}>0.05\right)$. However, the association of humidity or rainfall with temperature, or the temperature alone, had a negative effect on sand fly density $\left(\mathrm{R} \geq 0.680, \mathrm{r}^{2} \geq 0.462, \mathrm{p}<0.05\right)$.

The rainy season did not have an effect on the number of L. longipalpis captured $\left(\chi^{2}=1.22, \mathrm{df}=1, \mathrm{p}>0.05\right)$. This fact confirms that rainfall and humidity do not have an effect population density. Nevertheless, in the rainy season, more insects were captured in the intradomicile $\left(\chi^{2}=42.79, \mathrm{df}=1, \mathrm{p}<0.05\right)$ while in the dry season more insects were captured in the peridomicile $\left(\chi^{2}=31.71, \mathrm{df}=1, \mathrm{p}<0.05\right)$ (Table 3).

This study showed that more $L$. longipalpis flies were captured in the intradomicile during the dry season compared to the peridomicile where most of the specimens were collected during the rainy season. Possibly these insects are in search of a more humid environment. Several studies have demonstrated a clear relationship between abiotic factors (temperature, rainfall and humidity) and sand fly population density with interference in adult life cycles or a modification of breeding sites (CHANIOTIS et al., 1971; MONTEIRO et al., 2005; OLIVEIRA et al., 2008; MICHALSKY et al., 2009). The population decrease is expected after the peak rainfall due to destruction of breeding sites in flooded ground and pupa killing in the soil (DIAS et al., 2007). However, the rain and humidity did not significantly affect sand fly density. Similar data were reported in a monitoring survey conducted in 2005-2006 in Mossoró (AMÓRA et al., 2010), and in Várzea Grande, Mato Grosso do Sul, central-west Brazil (MISSAWA; DIAS, 2007). Yet it has been classically reported that rainy periods favor the proliferation and survival of sand flies (DEANE, L. M.; DEANE, M. P., 1955), during (XIMENES et al., 2006; MACEDO et al., 2008; QUEIROZ et al., 2009) or after the rainy months (DIAS et al., 2007).

The temperatures remained constant but high throughout the study. High temperatures alone or associated with other variables had a negative effect on sand flies, probably due to the long rainy season. This inverse correlation between sand flies and high temperature was also reported in the municipality of Nísia Floresta in Rio Grande do Norte (XIMENES et al., 2006), Campo Grande in Mato Grosso do Sul (OLIVEIRA et al., 2008) and Sobral in the state of Ceará (MACEDO et al., 2008). However, in Nísia Floresta, sand flies live at temperatures between $32-36^{\circ} \mathrm{C}$ and no 
Table 2. Lutzomyia longipalpis captured and mean environmental variables, temperature $\left({ }^{\circ} \mathrm{C}\right)$, relative humidity $(\%)$ and rainfall (mm), during the phlebotomine sand fly survey study. Mossoró, Rio Grande do Norte State, Northeastern Brazil, 2007.

\begin{tabular}{|c|c|c|c|c|c|c|}
\hline \multirow[t]{2}{*}{ Months } & \multicolumn{3}{|c|}{ Lutzomyia longipalpis } & \multicolumn{3}{|c|}{ Environmental variables } \\
\hline & Female & Male & Total & Temperature & Rainfall & Humidity \\
\hline January & $63 \mathrm{~A}$ & $92 \mathrm{~B}$ & $155 \mathrm{a}$ & $29.20 \mathrm{a}$ & $9.70 \mathrm{~b}$ & $72.41 \mathrm{ab}$ \\
\hline February & $110 \mathrm{~A}$ & $142 B$ & $252 b$ & $27.96 \mathrm{a}$ & $212.20 \mathrm{e}$ & $77.29 \mathrm{ab}$ \\
\hline March & $157 \mathrm{~A}$ & $172 B$ & $329 c$ & $27.01 \mathrm{a}$ & $389.30 \mathrm{f}$ & $80.98 b$ \\
\hline April & $351 \mathrm{~B}$ & $214 \mathrm{~A}$ & $565 e$ & $27.43 \mathrm{a}$ & $141.20 \mathrm{~d}$ & $78.41 \mathrm{ab}$ \\
\hline May & $527 \mathrm{~A}$ & $469 \mathrm{~A}$ & $996 \mathrm{~h}$ & $27.07 \mathrm{a}$ & $110.20 \mathrm{~d}$ & $74.85 \mathrm{ab}$ \\
\hline June & $366 \mathrm{~A}$ & $455 \mathrm{~B}$ & $821 \mathrm{~g}$ & $26.71 \mathrm{a}$ & $42.40 \mathrm{c}$ & $72.65 \mathrm{ab}$ \\
\hline July & $1,080 \mathrm{~B}$ & $791 \mathrm{~A}$ & $1,871 \mathrm{i}$ & $27.65 \mathrm{a}$ & $5.00 \mathrm{~b}$ & $63.11 \mathrm{ab}$ \\
\hline August & $264 \mathrm{~A}$ & $395 B$ & $659 \mathrm{f}$ & $27.65 a$ & $0.00 \mathrm{a}$ & $55.76 \mathrm{a}$ \\
\hline September & $190 \mathrm{~A}$ & $238 \mathrm{~B}$ & $428 \mathrm{~d}$ & $28.46 \mathrm{a}$ & $0.00 \mathrm{a}$ & $57.00 \mathrm{a}$ \\
\hline October & $112 \mathrm{~A}$ & $154 \mathrm{~B}$ & $266 b$ & $28.73 a$ & $0.00 \mathrm{a}$ & $58.47 \mathrm{ab}$ \\
\hline November & $133 \mathrm{~A}$ & 182B & $315 c$ & $28.82 \mathrm{a}$ & $0.00 \mathrm{a}$ & $62.94 \mathrm{ab}$ \\
\hline December & $82 \mathrm{~A}$ & $156 \mathrm{~B}$ & $238 \mathrm{~b}$ & $28.80 \mathrm{a}$ & $33.20 \mathrm{c}$ & $66.63 \mathrm{ab}$ \\
\hline
\end{tabular}

Capital letters compare the columns and lower case letters the lines. Different letters indicate significantly different values by the chi-square test ( $\mathrm{p}<0.05)$.

Table 3. Distribution of Lutzomyia longipalpis by capture site (intra- or peridomicile) dry period (July-Nov) and rainy (Dec-June), during the phlebotomine sand fly survey study. Mossoró, Rio Grande do Norte State, Northeastern Brazil, 2007.

\begin{tabular}{|c|c|c|c|c|c|c|c|}
\hline \multirow[t]{2}{*}{ Rainfall } & \multicolumn{3}{|c|}{ Intradomicile } & \multicolumn{3}{|c|}{ Peridomicile } & \multirow[t]{2}{*}{ Overall } \\
\hline & Female & Male & Total & Female & Male & Total & \\
\hline Rainy period & $639 a$ & $607 a$ & $1,246 a$ & $1,017 \mathrm{a}$ & $1,093 \mathrm{a}$ & $2,110 \mathrm{a}$ & $3,356 \mathrm{a}$ \\
\hline Dry period & $361 b$ & $464 b$ & $825 b$ & $1,364 b$ & $1,296 b$ & $2,660 \mathrm{~b}$ & $3,485 \mathrm{a}$ \\
\hline Total & $1,000 \mathrm{~A}$ & $1,071 \mathrm{~A}$ & 2,071 & $2,381 \mathrm{~A}$ & $2,389 \mathrm{~A}$ & 4,770 & 6,841 \\
\hline
\end{tabular}

Capital letters compare the columns and lower case letters the lines. Different letters indicate significantly different values by the chi-square test ( $\mathrm{p}<0.05)$.

significant correlation was found between population density and temperature (XIMENES et al., 2000).

Despite the absence of human VL cases in the dwelling studied, the presence of the vector species in such high numbers associated with a high prevalence of canine VL (AMÓRA et al., 2006, MATOS et al., 2006) is indicative of an area with potential risk of transmission of this zoonosis to humans. Similar data were reported in Janaúba, Minas Gerais (MICHALSKY et al., 2009).

The present study showed that $L$. longipalpis is the predominant species in Mossoró and is present in significant numbers throughout the year. It stresses the difficulty of implementing standard vector control measures due to the particularities of each region. Given the high number of insects caught in the intradomicile, we thus recommend intensification of VL control measures in Mossoró including health education.

In conclusion, the eco-epidemiological profile of VL is complex and shows particularities in each area of transmission. Studies on the behavior of sand flies in specific units of endemic areas can provide input to public health authorities for planning appropriate $\mathrm{VL}$ vector control measures.

\section{Acknowledgments}

To Dr. Nélio B. Morais, Lindemberg Caranha and Richristi A. Silva (SESA/CE), Ana Claudia B. Mendonça, Sodré Rocha (Secretaria Municipal de Saúde de Mossoró) for their help with sand fly field collections; Dr. Rui Sales Júnior, Dr. Celicina M. S. B. Azevedo (UFERSA) for their help; and to UFERSA administrative staff for logistic support; Lorena M. B. Oliveira Msc for reviewing the manuscript and the population of the areas studied for their patience and kindness.

\section{References}

AMÓRA, S. S. A. et al. Fatores relacionados com a positividade de cáes para leishmaniose visceral em área endêmica do Estado do Rio Grande do Norte, Brasil. Ciência Rural, v. 36, n. 6, p. 1854-1859, 2006.

AMÓRA, S. S. A. et al. Monitoring of Lutzomyia longipalpis Lutz \& Neiva, 1912 in an area of intense transmission of visceral leishmaniasis in Rio Grande do Norte, Northeast Brazil. Revista Brasileira de Parasitologia Veterinária, v. 19, n. 1, p. 41-45, 2010.

ARANSAY, A. M.; SCOULICA, E.; TSELENTIS, Y. Detection and identification of Leishmania DNA within naturally infected sand flies by seminested PCR on minicircle kinetoplastic DNA. Applied and Environmental Microbiology, v. 66, n. 5, p. 1933-1938, 2000.

BARATA, R. A. et al. Aspectos da ecologia e do comportamento de flebotomíneos em área endêmica de leishmaniose visceral, Minas Gerais. Revista da Sociedade Brasileira de Medicina Tropical, v. 38, n. 5, p. 421-425, 2005.

BARATA, R. A. et al. Flebotomíneos do Parque Nacional Cavernas do Peruaçu, MG. Neotropical Entomology, v. 37, n. 2, p. 226-228, 2008.

CHANIOTIS B. N. et al. Natural population dynamics of phlebotomine sandflies in Panama. Journal of Medical Entomology, v. 8, n. 4, p. 339-352, 1971. 
CORTEZ, A. M. et al. Vertical stratification and development aspects of phlebotomine sand flies (Diptera: Psychodidae) in an area of Atlantic Forest tree species in a metropolitan region in northeastern Brazil. Journal of Vector Ecology, v. 32, n. 2, p. 336-341, 2007.

DEANE, L. M.; DEANE, M. P. Leishmaniose visceral urbana (no cão e no homem) em Sobral, Ceará. O Hospital, v. 47, p. 75-87. 1955.

DIAS, E. S. et al. Flebotomíneos (Diptera: Psychodidae) de um foco de leishmaniose tegumentar no Estado de Minas Gerais. Revista da Sociedade Brasileira de Medicina Tropical, v. 40, n. 1, p. 49-52, 2007.

GALATI, E. A. B. et al. Phlebotomines (Diptera, Psychodidae) in caves of the Serra da Bodoquena, Mato Grosso do Sul State, Brazil. Revista Brasileira de Entomologia, v. 47, n. 2, p. 283-296, 2003.

GALATI, E. A. B. Morfologia e taxonomia: morfologia, terminologia de adultos e identificação dos táxons da América. In: RANGEL, E.F.; LAINSON, R. Flebotomíneos do Brasil. Rio de Janeiro: Fiocruz, 2003. p. $53-175$.

INSTITUTO BRASILEIRO DE GEOGRAFIA E ESTATÍSTICA - IBGE. População recenseada e estimada, segundo os municípios, Rio Grande do Norte, 2007. Available from: <http://www.ibge.gov.br>. Access in: 30 Aug. 2008.

INSTITUTO DE DEFESA DO MEIO AMBIENTE. GOVERNO DO RIO GRANDE DO NORTE - IDEMA. Perfil do seu município. 2002. Available from: <http://www.rn.gov.br>. Access in: 30 Aug. 2008.

LAINSON, R.; RANGEL, E. F. Lutzomyia longipalpis and the eco-epidemiology of American visceral leishmaniasis, with particular reference to Brazil: a review. Memórias do Instituto Oswaldo Cruz, v. 100 , n. 8 , p. $811-827,2005$.

MACEDO, I. T. F. et al. Sazonalidade de flebotomíneos em área endêmica de leishmaniose visceral no município de Sobral, Ceará, Brasil. Ciência Animal, v. 18, n. 2, p. 67-74, 2008.

MATOS, M. M. et al. Ocorrência da leishmaniose visceral em cães em Mossoró, Rio Grande do Norte. Ciência Animal, v. 16, n. 1, p. 51-54, 2006.

MICHALSKY, É. M. et al. Phlebotominae distribution in Janaúba, an area of transmission for visceral leishmaniasis in Brazil. Memórias do Instituto Oswaldo Cruz, v. 104, n. 1, p. 56-61, 2009.

MINISTÉRIO DA SAÚDE. Secretaria de Vigilância em Saúde. Departamento de Vigilância Epidemiológica. 2006. Manual de vigilância e controle da leishmaniose visceral. Brasília: Ministério da Saúde. Available from: <http://portal.saude.gov.br/portal/arquivos/pdf/ manual_leish_visceral2006.pdf >. Access in 30 Aug. 2008. 122 p.

MISSAWA, N. A.; DIAS, E. S. Phlebotomine sand flies (Diptera: Psychodidae) in the municipality of Várzea Grande: an area of transmission of visceral leishmaniasis in the state of Mato Grosso, Brazil. Memórias do Instituto Oswaldo Cruz, v. 102, n. 8, p. 913-918, 2007.

MONTEIRO, E. M. et al. Leishmaniose visceral: estudo de flebotomíneos e infecção canina em Montes Claros, Minas Gerais. Revista da Sociedade Brasileira de Medicina Tropical, v. 38, n. 2, p. 147-152, 2005.

OLIVEIRA, A. G. et al. Seasonal variation of Lutzomyia longipalpis (Lutz and Neiva, 1912) (Diptera: Psychodidae: Phlebotominae) in endemic area of visceral leishmaniasis, Campo Grande, state of Mato Grosso do Sul, Brazil. Acta Tropica, v. 105, n. 1, p. 55-61, 2008.

PAULA, C. C. et al. Leishmaniose visceral canina em Maricá, Estado do Rio de Janeiro: relato do primeiro caso autóctone. Revista da Sociedade Brasileira de Medicina Tropical, v. 42, n. 1, p. 77-78, 2009.

PINTO, I. S. et al. American visceral leishmaniasis dissociated from Lutzomyia longipalpis (Diptera, Psychodidae) in the State of Espírito Santo, Brazil. Cadernos de Saúde Pública, v. 26, n. 2, p. 365-372, 2010 .

QUEIROZ, P. V. S. et al. Canine visceral leishmaniasis in urban and rural areas of Northeast Brazil. Research in Veterinary Science, v. 86, n. 2, p. 267-273, 2009.

REBÊLO, J. M. M. et al. Ocorrência de flebotomíneos (Diptera, Psychodidae) em focos de leishmanioses, em área de ecoturismo do entorno do Parque Nacional dos Lençóis Maranhenses, Brasil. Cadernos de Saúde Pública, v. 26, n. 1, p. 195-198, 2010.

REBÊLO, J. M. M. Freqüência horária e sazonalidade de Lutzomyia longipalpis (Diptera: Psychodidae: Phlebotominae) na Ilha de São Luís, Maranhão, Brasil. Cadernos de Saúde Pública, v. 17, n. 1, p. 221-227, 2001.

XIMENES, M. F. F. M. et al. Distribution of Phlebotomine Sand Flies (Diptera: Psychodidae) in the State of Rio Grande do Norte, Brazil. Journal of Medical Entomology, v. 37, n. 1, p. 162-169, 2000.

XIMENES, M. F. F. M. et al. Effect of Abiotic factors on seasonal population dynamics of Lutzomyia longipalpis (Diptera: Psychodidae) in Northeastern Brazil. Journal of Medical Entomology, v. 43, n. 5 , p. 990-995, 2006.

XIMENES, M. F. F. M. et al. Flebotomíneos (Diptera: Psychodidae) e leishmanioses no Rio Grande do Norte, Nordeste do Brasil: reflexos do ambiente antrópico. Neotropical Entomology, v. 36, n. 1, p. 128-137, 2007.

XIMENES, M. F. F. M.; SOUZA, M. F.; CASTELLÓN, E. G. Density of sand flies (Diptera: Psychodidae) in domestic and wild animal shelters in an area of visceral leishmaniasis in the State of Rio Grande do Norte, Brazil. Memórias do Instituto Oswaldo Cruz, v. 94, n. 4, p. 427-432, 1999. 